\title{
PERAN DINAS LINGKUNGAN HIDUP KOTA SEMARANG TERHADAP PELAKSANAAN PEMBANGUNAN BERWAWASAN LINGKUNGAN
}

\author{
Mastur, Muhamad Mas'ud, \\ Fakultas Hukum Universitas Wahid Hasyim Semarang \\ Email : mastur_unwahas@yahoo.com,Muhammadmasud0501@gmail.com
}

\begin{abstract}
ABSTRAK
Proses pembangunan di kota Semarang mengakibatkan mobilitas penduduk semakin meningkat sehingga keadaan ini membuka peluang untuk meningkatkan sistem perekonomian dan meningkatnya masalah pencemaran. Upaya pembangunan lingkungan hidup yang berwawasan lingkungan diharapkan mampu mendukung masyarakat dalam memenuhi kebutuhan yang dimilikinya dengan tetap memperhatikan lingkungan hidup. Penelitian ini bertujuan untuk mengetahui peran Dinas Lingkungan Hidup Kota Semarang terhadap pelaksanaan pengelolaan pembangunan berwawasan lingkungan di kota Semarang dan untuk mengetahui kenndala yang dihadapi oleh Dinas Lingkungan Hidup kota Semarang terhadap pelaksanaan pengelolaan pembangunan berwawasan lingkungan. Metode yang digunakan dalam penelitian ini adalah penelitian hukum normatif dengan pendekatan yang digunakan pendekatan perundang-undangan, pendekatan kasus dan pendekatan perbandingan.

Hasil penelitian diperoleh bahwa peran Dinas Lingkungan Hidup kota Semarang dalam melaksanakan pengelolaan pembangunan berwawasan lingkungan di kota Semarang berpedoman pada Peraturan Walikota Semarang Nomor 72 Tahun 2016 tentang Kedudukan Tugas Pokok dan Fungsinya. Kendala yang dihadapi oleh Dinas Lingkungan Hidup Kota Semarang dalam melaksanakan pengelolaan pembangunan berwawasan lingkungan di Kota Semaran adalah kurangnya pemahaman tentang nilai-nilai bersama bagi sumber daya alam, kondisi daya dukung lingkungan hidup semakin menurun; kurangnya kepedulian masyarakat dan dunia usaha dalam perilaku budaya yang ramah lingkungan.Untuk mengatasi kendala-kendala terhadap pelaksanaan pengelolaan pembangunan berwawasan lingkungan di kota Semarang yaitu dengan penanggulangan pencemaran air udara dan tanah, pelestarian keanekaragaman hayati, pengembangan lembaga daerah dan lembaga pusat studi lingkungan, pembinaan sarana informasi yang menunjang pengelolaan lingkungan, pengembangan peraturan perundang-undangan.
\end{abstract}

Kata Kunci : Peran Dinas Lingkungan Hidup, Pembangunan, Berwawasan Lingkungan 


\section{A. Pendahuluan}

Usaha untuk meningkatkan kualitas hidup telah dimulai sejak peradaban manusia ribuan tahun yang silam, yaitu dalam usaha mendapatkan kesenangan hidup yang akan dinikmati diri sendiri maupun untuk diwariskan kepada generasi yang akan datang. Peningkatan kualitas ini tentunya telah terasa sejak adanya revolusi yang ada di Eropa dengan ditandai dengan adanya revolusi industri. ${ }^{40}$ Upaya pengelolaan lingkungan hidup mencakup segala sesuatu yang ada di lingkungan itu sendiri, termasuk didalamnya benda, zat organik, dan manusia. Peranan manusia sebagai mahluk yang diberikan kelebihan akal dan fikiran, harus dapat menciptakan hubungan timbal balik secara harmonis. Untuk itu dalam rangka pengelolaan lingkungan hidup peranan manusia sangat menentukan. Manusia dapat merusak dan mencemarkan lingkungan, tetapi sebaliknya manusia juga dapat menjadi penyelamat dan pemelihara lingkungan. ${ }^{41}$

Pencemaran lingkungan yang kini dirasakan, berkaitan erat dengan perkembangan ilmu pengetahuan dan teknologi yang semakin maju, pola-pola hidup yang semakin mewah, tingkah laku manusia yang tidak terkontrol dan lain sebagainya. Masalah pencemaran timbul bilamana suatu zat atau energy dengan tingkat konsentrasi yang sedemikian rupa dapat merubah kondisi lingkungan, baik secara langsung maupun tidak langsung dan pada akhirnya lingkungannya tidak lagi berfungsi sebagaimana mestinya. ${ }^{42}$

Untuk mencegah dan mengatasi pencemaran oleh limbah industri, pemerintah harus berperan aktif baik melalui perundang-undangan ataupun dengan cara yang lain. Pemerintah harus menggiatkan pembangunan yang berkesinambungan yaitu sustainable development dengan artian pembangunan

\footnotetext{
${ }^{40}$ Nurpiandi, 2015, Peran Badan Lingkungan Hidup Tanjungpinang Dalam Memberikan Informasi Tentang Lingkungan Hidup Kepada Masyarakat Di Kota Tanjungpinang, Jurnal, Universitas Maritim Raja Ali Haji Tanjungpinang.

${ }^{41}$ Nurpiandi, 2015, Peran Badan Lingkungan Hidup Tanjungpinang Dalam Memberikan Informasi Tentang Lingkungan Hidup Kepada Masyarakat Di Kota Tanjungpinang, Jurnal, Universitas Maritim Raja Ali Haji Tanjungpinang.

${ }^{42}$ Ibid.
} 
yang berwawasan ke depan dengan maksud agar mampu dimanfaatkan oleh generasi sekarang maupun yang akan datang. Pemerintah juga harus menggariskan kebijaksanaan dan mendorong ditingkatnya upaya pelestarian kemampuan lingkungan hidup untuk menunjang pembangunan yang berkesinambungan. ${ }^{43}$

Keadaan ini mendorong Pemerintah Kota Semarang khususnya Badan Lingkungan Hidup Kota Semarang untuk melakukan upaya pengendalian dampak lingkungan hidup sehingga resiko terhadap lingkungan hidup dapat ditekan sekecil mungkin. Meskipun Pemerintah Kota Semarang sudah mengeluarkan Peraturan Daerah Kota Semarang Nomor 13 Tahun 2006 tentang Pengendalian Lingkungan Hidup dengan berpedoman pada UndangUndang Republik Indonesia Nomor 32 Tahun 2009 tentang Perlindungan Lingkungan Hidup namun masih tetap terjadi pencemaran lingkungan khususnya di Kota Semarang.

Berdasarkan uraian latar belakang masalah tersebut di atas, maka penulis akan membahas tentang Peran Dinas Lingkungan Hidup Kota Semarang terhadap pelaksanaan pengelolaan pembangunan berwawasan lingkungan, Kendala dan upaya yang dihadapi Dinas Lingkungan Hidup Kota Semarang Terhadap Pelaksanaan Pengelolaan Pembangunan Berwawasan Lingkungan di Kota Semarang.

\section{B. Pembahasan}

\section{Peran Dinas Lingkungan Hidup Kota Semarang Terhadap} Pelaksanaan Pengelolaan Pembangunan Berwawasan Lingkungan di

\section{Kota Semarang}

Konsep pembangunan yang berkelanjutan mengimplikasikan bukan pada batas absolut tetapi pada batas yang ditentukan oleh tingkat masyarakat dan organisasi sosial mengenai sumber daya alam serta kemampuan biosfer untuk menyerap pengaruhpengaruh kegiatan manusia. Sumber alam terdiri atas, pertama, yang bisa diperbaharui (renewable

${ }^{43}$ Siahaan, N.H.T. 2008. Hukum Lingkungan. Jakarta: Pancuran Alam. Hlm. 2. 
resource) seperti kayu, tumbuhan dan lain sebagainya, kedua, yang tidak bisa diperbaharui (nonrenewable resorce) seperti batu bara, minyak bumi, dan lain sebagainya. Mengingat bahwa dalam sumber alam terdapat, suatu sumber daya alam yang tidak dapat diperbaharui maka dalam pengelolaan sumber alam perlu memperhitungkan hal-hal sebagai berikut :

1) Segi keterbatasan jumlah dan kualitas sumber alam;

2) Lokasi sumber alam serta pengaruhnya terhadap pertumbuhan masyarakat dan pembangunan daerah;

3) Penggunaan sumber alam yang tidak boros; dan

4) Dampak negatif pengelolaan berupa limbah dipecahkan secara bijak termasuk kemana membuangnya dan sebagainya. ${ }^{44}$

Berkaca dengan pernyataan yang disampaikan oleh Emil Salim ini, pemerintah kota Semarang berusaha untuk melakukan perubahan yang signifikan terhadap pembangunan dengan mengedepankan lingkungan yang didalamnya tentunya berkaitan erat dengan standar dan mutu masyarakat. Hal ini merupakan suatu pernyataan bahwa dalam melakukan pembangunan disegala bidang, pemerintah kota Semarang tetap memperhatikan berbagai hal yang berhubungan dengan lingkungan masyarakat. Untuk itu dalam melakukan pengelolaan lingkungan dan pengawasannya ini, pemerintah kota Semarang juga memperhatikan berbagai faktor diantaranya adalah :

1) Jumlah, kualitas dan lokasi penduduk;

2) Teknologi yang dipakai;

3) Pola hidup yang mengkonsumsi sumber alam. Jumlah penduduk, kualitas penduduk serta lokasi penduduk di kota Semarang juga ikut menentukan berjalannya pembangunan yang berwawasan lingkungan. hal ini merupakan suatu pernyataan yang memiliki suatu hubungan korelasi yang searah karena dengan mengedepankan suatu pemikiran bahwa dengan mempelajari

${ }^{44}$ Emil Salim, 1986, Pembangunan Berwawasan Lingkungan, LP3S, Jakarta, hal. 170 
kualitas dan jumlah serta lokasi penduduk, maka pembangunan yang berwawasan lingkungan akan berjalan sebagaimana mestinya.

Menurut hasil wawancara penulis dengan Ibu Ir. Yuni Hastuti, M.T, bahwa, peran Dinas Lingkungan Hidup Kota Semarang dalam melaksanakan pengelolaan pembangunan berwawasan lingkungan di Kota Semarang selalu berpedoman pada Peraturan Walikota Semarang Nomor 72 Tahun 2016 tentang Kedudukan Tugas Pokok dan Fungsi. Dinas Lingkungan Hidup membantu Walikota Semarang dalam urusan pemerintahan bidang Lingkungan Hidup, bidang Pekerjaan Umum dan Penataan Ruang sub urusan persampahan dan air limbah serta bidang Kehutanan. $^{45}$

Lebih lanjut dikatakan bahwa disamping itu, peran Dinas Lingkungan Hidup Kota Semarang dalam pelaksanaan pengelolaan pembangunan berwawasan Lingkungan di Kota Semarang juga berpedoman pada peraturan perundang-undangan, yaitu :

1) Undang-undang Dasar Tahun 1945 Pasal 33 ayat (3);

2) Undang-undang Nomor 32 Tahun 2009 tentang Perlindungan dan Pengelolaan Lingkungan Hidup;

3) Peraturan Pemerintah Nomor 27 Tahun 1999 tentang Analisis Mengenai Dampak Lingkungan;

4) Peraturan Daerah Provinsi Jawa Tengah Nomor 5 Tahun 2007 tentang Pengendalian Lingkungan Hidup di Provinsi Jawa Tengah;

5) Peraturan Daerah Kota Semarang Nomor 13 Tahun 2006 tentang Pengendalian Lingkungan Hidup. ${ }^{46}$

Dinas Lingkungan Hidup dalam melaksanakan tugas sebagaimana dimaksud dalam Pasal 4 menyelenggarakan fungsi ${ }^{47}$ :

\footnotetext{
${ }^{45}$ Hasil wawancara penulis dengan Ibu Ir. Yuni Hastuti, MT., Kasubag Perencanaan dan Evaluasu pada Dinas Lingkungan Hidup Kota Semarang, tanggal 20 April 2018.

${ }^{46}$ Hasil wawancara penulis dengan Ibu Ir. Yuni Hastuti, MT., Kasubag Perencanaan dan Evaluasu pada Dinas Lingkungan Hidup Kota Semarang, tanggal 20 April 2018.

${ }^{47}$ Peraturan Walikota Nomor 72 Tahun 2016 tentang Kedudukan, Susunan Organisasi, Tugas dan Fungsi, serta Tata Kerja Dinas Lingkungan Hidup Kota Semarang
} 
a. Perumusan kebijakan Bidang Penataan Lingkungan, Bidang Pengelolaan Sampah, Bidang Pengendalian Pencemaran dan Konservasi Lingkungan Hidup, Bidang Pengawasan dan Pemberdayaan Lingkungan, dan UPTD;

b. perumusan rencana strategis sesuai dengan visi dan misi Walikota;

c. pengkoordinasian tugas-tugas dalam rangka pelaksanaan program/kegiatan Kesekretariatan, Bidang Penataan Lingkungan, Bidang Pengelolaan Sampah, Bidang Pengendalian Pencemaran dan Konservasi Lingkungan Hidup, Bidang Pengawasan dan Pemberdayaan Lingkungan, dan UPTD;

d. penyelenggaraan pembinaan kepada bawahan dalam lingkup tanggungjawabnya;

e. penyelenggaraan penyusunan Sasaran Kerja Pegawai;

f. penyelenggaraan kerjasama Bidang Penataan Lingkungan, Bidang Pengelolaan Sampah, Bidang Pengendalian Pencemaran dan Konservasi Lingkungan Hidup, Bidang Pengawasan dan Pemberdayaan Lingkungan, dan UPTD;

g. penyelenggaraan kesekretariatan Dinas Lingkungan Hidup;

h. penyelenggaraan program dan kegiatan Bidang Penataan Lingkungan, Bidang Pengelolaan Sampah, Bidang Pengendalian Pencemaran dan Konservasi Lingkungan Hidup, Bidang Pengawasan dan Pemberdayaan Lingkungan, dan UPTD;

i. penyelenggaraan penilaian kinerja Pegawai;

j. penyelenggaraan monitoring dan evaluasi program dan kegiatan Bidang Penataan Lingkungan, Bidang Pengelolaan Sampah, Bidang Pengendalian Pencemaran dan Konservasi Lingkungan Hidup, Bidang Pengawasan dan Pemberdayaan Lingkungan, dan UPTD;

k. penyelenggaraan laporan pelaksanaan program dan kegiatan; dan

1. pelaksanaan fungsi lain yang diberikan oleh Walikota terkait dengan tugas dan fungsinya. 
Adapun sarana dan prasarana yang dimiliki Dinas Lingkungan Hidup Kota Semarang dapat dilihat pada Tabel 4.1

Tabel 4.1

Jumlah Kendaraan Bermotor

Dinas Lingkungan Hidup Kota Semarang

\begin{tabular}{|l|l|c|c|}
\hline NO & \multicolumn{1}{|c|}{ JENIS KENDARAAN } & NO. STNK & TAHUN \\
\hline A & Roda Empat berjumlah 9 buah : & & \\
\hline 1 & Mobil Toyota Inova & H 47 A & 2007 \\
\hline 2 & Mobil Toyota Kijang & H 9518 SA & \\
\hline 3 & Mobil Toyota Hilux Pic'up & H 9566 AH & 2015 \\
\hline 4 & Mobil Toyota Avanza & H 9526 SA & 2008 \\
\hline 5 & Mobil Toyota Avanza & H 9524 RS & 2009 \\
\hline 6 & Mobil Toyota Avanza & H 9516 TS & 2013 \\
\hline 7 & Mobil Toyota Avanza & H 79 A & 2005 \\
\hline 8 & Mobil Ford Ranger 2,5 L & H 9579 YY & 2009 \\
\hline 9 & Mobil APV & H 9527 TS & 2013 \\
\hline 10 & Mobil Nisan Navara & H 9584 AH & 2015 \\
\hline B & Roda Dua berjumlah 4 buah : & H 9963 MA & 2015 \\
\hline 1 & Motor Honda Supra 125 cc & H 9968 QS & 2009 \\
\hline 2 & Motor Honda Revo & 2009 \\
\hline 3 & Motor Honda Revo & 2007 \\
\hline 4 & Motor Honda Revo & RS & \\
\hline
\end{tabular}

Sumber : Data Jumlah Kendaraan Bermotor Dinas Lingkungan Hidup

Kota Semarang

Ketersediaan anggaran belanja daerah yang dialokasikan pada Dinas Lingkungan Hidup (DLH) Kota Semarang tidak kalah pentingnya dalam menentukan pencapaian program dan kegiatan yang telah diamanatkan dalam rencana kerja tahun 2017, walaupun disadari masih banyak program dan kegiatan yang belum tersentuh dengan baik sehingga diperlukan perencanaan dan alokasi anggaran yang memadai. Untuk tahun anggaran 2017, jumlah 
anggaran yang dialokasikan untuk belanja langsung sebesar Rp. 98.609.856.000,- (Sembilan puluh delapan milyar enam ratus Sembilan juta delapan ratus lima puluh enam ribu rupiah). ${ }^{48}$

Oleh karena itu dalam melaksanakan tugas pokok dan fungsinya, agar anggaran yang ada dapat lebih dioptimalkan dalam mengkoordinasikan pelaksanaan kebijakan di bidang Lingkungan Hidup, bidang Pekerjaan Umum dan Penataan Ruang sub urusan persampahan dan air limbah serta bidang Kehutanan meliputi penataan lingkungan, pengelolaan sampah, pengendalian pencemaran dan konservasi Lingkungan Hidup, Pengawasan dan Pemberdayaan Lingkungan serta operasional UPTD maka perlu senantiasa melakukan koordinasi, sinkronisasi dan implementasi yang diterapkan di dalam melaksanakan tugas-tugas pokok dan fungsi.

Realisasi capaian keuangan yang dicapai Dinas Lingkungan Hidup (DLH) Kota Semarang tahun 2017 dari rencana kerja yang telah ditetapkan hingga bulan Desember 2017 dapat diuraikan pada tabel 4.2

Tabel 4.2

Uraian Realisasi Anggaran DLH Kota Semarang Tahun 2017

\begin{tabular}{|c|c|c|c|c|}
\hline No & URAIAN & $\begin{array}{c}\text { ANGGARAN } \\
(\mathbf{R p})\end{array}$ & $\begin{array}{c}\text { REALISASI } \\
(\mathbf{R p})\end{array}$ & $\%$ \\
\hline & BELANJA & & & \\
\hline & $\begin{array}{c}\text { a. Belanja Tidak Langsung } \\
\text { - Belanja pegawai }\end{array}$ & $\mathbf{3 . 7 9 7 . 2 2 4 . 8 9 7}$ & $\mathbf{3 . 5 7 3 . 4 5 0 , 7 9 3}$ & 94.11 \\
\hline $\begin{array}{c}\text { b. Belanja Langsung } \\
\text { - Belanja pegawai }\end{array}$ & $\mathbf{1 2 . 9 2 3 . 4 0 3 . 8 2 0}$ & $\mathbf{1 1 . 9 0 7 . 3 7 8 , 2 1 8}$ & 92.14 \\
\hline - Belanja barang dan & 5.803 .976 .840 & $5.369 .862,818$ & 92.52 \\
\hline - Belanja modal & 4.810 .212 .980 & $4.338 .503,900$ & 90.19 \\
\hline JUMLAH & $\mathbf{1 6 . 7 2 0 . 6 2 8 . 7 1 7}$ & $\mathbf{1 5 . 4 8 0 . 8 2 9 . 0 1 1}$ & $\mathbf{9 2 . 5 6}$ \\
\hline
\end{tabular}

Sumber : Data Realisasi Anggaran Dinas Lingkungan Hidup Kota Semarang

\footnotetext{
${ }^{48}$ Hasil wawancara penulis dengan Ibu Ir. Yuni Hastuti, MT., Kasubag Perencanaan dan Evaluasu pada Dinas Lingkungan Hidup Kota Semarang, tanggal 20 April 2018.
} 
Dari tabel 4.2 tersebut di atas dapat dilihat bahwa realisasi capaian keuangan yang dicapai Dinas Lingkungan Hidup (DLH) Kota Semarang tahun 2017 dari rencana kerja yang telah ditetapkan hingga bulan Desember 2017 mencapai 92,56\%. Sehingga dalam hal ini penulis dapat menyimpulakan bahwa peran Dinas Lingkungan Hidup Kota Semarang terhadap pelaksanaan pengelolaan pembangunan di Kota Semarang sudah baik. Meski demikian perlu diupayakan dan ditingkatkan lagi dalam realisasi pembangunan berwawasan lingkungan di Kota Semarang, mengingat masih ada keuangan sebesar 7,44\% yang belum sempat terserap atau belum sempat digunakan.

\section{Kendala-kendala yang dihadapi oleh Dinas Lingkungan Hidup Kota} Semarang Terhadap Pelaksanaan Pengelolaan Pembangunan Berwawasan Lingkungan di Kota Semarang

Menurut Surna T. Djajadiningrat pencapaian pembangunan berkelanjutan mensyaratkan $^{49}: 44$

1) Suatu sistem politik yang menjamin partisipasi aktif masyarakat dalam pengambilan keputusan;

2) Suatu sistem ekonomi yang mampu menghasilkan surplus serta pengetahuan teknis berdasarkan kemampuan sendiri dan berlanjut;

3) Suatu sistem sosial yang memberikan penyelesaian bagi keteganganketegangan yang muncul akibat pembangunan yang tidak selaras;

4) Suatu sistem produksi yang menghormati kewajiban untuk melestarikan ekologi bagi pembangunan;

5) Suatu sistem teknologi yang dapat menemukan secara terus menerus jawaban-jawaban baru;

6) Suatu sistem internasional yang dapat membantu perkembangan hak-hak perdagangan dan hubungan yang berlanjut;

\footnotetext{
${ }^{49}$ Muhammad Erwin, Op. Cit.,hal. 97.
} 
7) Suatu sistem administrasi yang luwes dan mempunyai kemampuan untuk memperbaiki diri.

Hal ini berarti bahwa pembangunan yang berkelanjutan bukanlah sebagai suatu tingkat keselarasan yang tetap, akan tetapi berupa sebuah proses pemanfaatan sumber daya, arah investasi, orientasi pengembangan teknologi, serta perubahan kelembagaan yang konsisten dengan kebutuhan dari depan dan hari ini, sehingga pembangunan berkelanjutan akan bersandar pada kemauan politik. Proses pembangunan berkelanjutan bertumpu pada tiga faktor sebagai berikut ${ }^{50}$ :

1) Faktor Kondisi sumber daya alam.

Sumber daya alam yang dapat menopang proses pembangunan secara berkelanjutan perlu memiliki kemampuan agar dapat berfungsi secara berkesinambungan. Bagi sumber daya yang dapat diperbaharui, perlu diolah dalam batas kemampuan pulihnya. Bila batas itu terlampaui, sumber daya alam tidak dapat memperbaharui dirinya sehingga tidak dapat menopang proses pembangunan yang mengandalkan sumber daya alam yang tidak dapat diperbaharui, pemanfaataannya perlu dilakukan secara efisien serta perlu mengembangkan tekonologi yang mampu mensubtitusikan bahan substitusinya.

2) Faktor Kualitas lingkungan.

Antara lingkungan dan sumber daya alam terdapat hubungan timbal balik yang erat. Semakin tinggi kualitas lingkungan maka akan semakin tinggi pada kualitas sumber daya alam yang mampu menopang pembangunan yang berkualitas.

3) Faktor kependudukan.

Faktor kependudukan ini adalah unsur yang dapat menjadikan model atau sebaliknya menjadi unsur yang menimbulkan dinamika dalam proses pembangunan. Karena itu faktor pembangunan perlu diubah dari faktor yang menambahkan beban pembangunan menjadi faktor yang merupakan modal pembangunan.

${ }^{50}$ RM. Gatot P. Soemartono, Op. Cit., hal. 6-7 
Menurut hasil wawancara penulis dengan Ibu Dra. Ratna Werdiati, Kasi Instrumen Penataan Lingkungan pada Dinas Lingkungan Hidup Kota Semarang bahwa kendala ataupun tantangan yang dihadapi oleh Dinas Lingkungan Hidup Kota Semarang dalam pengembangan pelayanan Dinas Lingkungan Hidup Kota Semarang adalah sebagai berikut ${ }^{51}$ :

1. Kurangnya pemahaman tentang nilai-nilai bersama bagi sumber daya yang tersedia sehingga menyebabkan penilaian aspek lingkungan hidup sangat dipengaruhi interpretasi yang subyektif;

2. Kondisi daya dukung lingkungan hidup semakin menurun;

3. Isu lingkungan hidup belum ditempatkan sebagai peluang untuk pembangunan ekonomi;

4. Kepedulian masyarakat dan dunia usaha yang masih harus ditingkatkan, didukung dengan perilaku budaya yang ramah lingkungan;

5. Kebijakan sector yang parsial dan kerjasama antar sector yang masih perlu ditingkatkan;

6. Pelaksanaan kebijakan lingkungan hidup belum sesuai dengan perencanaan;

7. Adanya faktor kepentingan dari masing-masing stakeholder;

8. Kurangnya keseriusan dan konsistensi penentu kebijakan dalam pengelolaan lingkungan hidup

Disamping itu juga terdapat kelemahan-kelemahan yang dialami oleh Dinas Lingkungan Hidup Kota Semarang, yaitu ${ }^{52}$ :

1. Anggaran Dinas Lingkungan Hidup belum mencukupi untuk melaksanakan tugas pokok dan fungsi Dinas Lingkungan Hidup Kota Semarang

2. Kualitas dan kuantitas Sumber Daya Manusia yang belum sebanding dengan peningkatan permasalahan lingkungan hidup

3. Lemahnya penaatan peraturan dan penegakan hukum dibidang lingkungan hidup

\footnotetext{
${ }^{51}$ Hasil wawancara penulis dengan Ibu Dra. Ratna Werdiati, Kasi Instrumen Penataan Lingkungan pada Dinas Lingkungan Hidup Kota Semarang, tanggal 23 April 2018.

52 Ibid.
} 
4. Sarana dan prasarana yang belum mencukupi untuk melaksankan kegiatan operasional pengelolaan lingkungan

5. Kurang optimalnya pengawasan dan pemantauan penaatan pelaksanaan dokumen AMDAL dan UKL-UPL

6. Kurang optimalnya pengawasan dan pengendalian pencemaran air, udara, bahan galian Golongan $\mathrm{C}$, penggunaan B3 dan penanganan limbah B3, limbah domestik dan pemanfaatan Air Bawah Tanah (ABT).Menurut Ibu Dra. Ratna Werdiati, Kasi Instrumen Penataan Lingkungan pada Dinas Lingkungan Hidup Kota Semarang. ${ }^{53}$

Lebih lanjut dikatakan oleh Ibu Dra. Ratna Werdiati, Kasi Instrumen Penataan Lingkungan pada Dinas Lingkungan Hidup Kota Semarang, bahwa persoalan yang sering muncul adalah terjadi air pasang laut (Rob) di beberapa bagian di wilayah perencanaan yang menjadi langganan genangan akibat rob. Saluran drainase yang mestinya menjadi saluran pembuangan air ke laut berfungsi sebaliknya (terjadi Backwater), sehingga sistem drainase yang ada tidak dapat berjalan dengan semestinya. Hal ini menjadi lebih parah bila terjadi hujan pada daerah tangkapan dari saluran-saluran drainase yang ada. Sehingga terjadi luas genangan yang semakin besar dan semakin tinggi.

\section{Upaya Yang Di Lakukan oleh Dinas Lingkungan Hidup Kota Semarang} Dalam Mengatasi Kendala-kendala Terhadap Pelaksanaan Pengelolaan Pembangunan Berwawasan Lingkungan di Kota Semarang

Sebagaimana penjelasan Ibu Dra. Ratna Werdiati, Kasi Instrumen Penataan Lingkungan pada Dinas Lingkungan Hidup Kota Semarang dalam wawancara yang dilakukan oleh penulis, bahwa upaya-upaya yang dilakukan oleh Dinas Lingkungan Hidup Kota Semarang dalam mengatasi kendala atau hambatan terhadap pelaksanaan pengelolaan pembangunan berwawasan lingkungan di kota Semarang, antara lain :

\footnotetext{
${ }^{53}$ Hasil wawancara penulis dengan Ibu Dra. Ratna Werdiati, Kasi Instrumen Penataan Lingkungan pada Dinas Lingkungan Hidup Kota Semarang, tanggal 23 April 2018.
} 
1) Pengelolaan sumber daya alam perlu direncanakan sesuai dengan daya dukung, setiap daerah harus dibangun sesuai dengan zona industri, zona pemukiman, zona perkebunan, pertanian dan lain-lain. Hal ini memerlukan perencanaan tata ruangan.

2) Proyek pembangunan yang berdampak negatif terhadap lingkungan dikendalikan melalui penerapan Analisis Mengenai Dampak Lingkungan sebagai bagian dari studi kelayakan dalam proses perencanaan proyek. Melalui studi AMDAL.

3) Pengendalian kerusakan lingkugnan melalui:

4) Pemanfaatan kebijakan ekonomi yang memuat pertimbangan lingkungan

5) Pengembangan peran serta masyarakat,kelembagaan dan ketenagakerjaan dalam pengelolaan lingkungan hidup.

6) Pengembangan kerjasama luar negeri.

\section{Simpulan}

Berdasarkan uraian yang telah dibahas di bab sebelumnya, maka dapat disimpulkan sebagai berikut :

1. Peran Dinas Lingkungan Hidup Kota Semarang dalam melaksanakan pengelolaan pembangunan berwawasan lingkungan di Kota Semarang selalu berpedoman pada Peraturan Walikota Semarang Nomor 72 Tahun 2016 tentang Kedudukan Tugas Pokok dan Fungsi. Dinas Lingkungan Hidup membantu Walikota Semarang dalam urusan pemerintahan bidang Lingkungan Hidup, bidang Pekerjaan Umum dan Penataan Ruang sub urusan persampahan dan air limbah serta bidang Kehutanan.

2. Kendala yang dihadapi oleh Dinas Lingkungan Hidup Kota Semarang dalam melaksanakan pengelolaan pembangunan berwawasan lingkungan di Kota Semaran adalah Kurangnya pemahaman tentang nilai-nilai bersama bagi sumber daya yang tersedia sehingga menyebabkan penilaian aspek lingkungan hidup sangat dipengaruhi interpretasi yang subyektif, Kondisi daya dukung lingkungan hidup semakin menurun, kepedulian masyarakat dan dunia usaha yang masih harus ditingkatkan, 
didukung dengan perilaku budaya yang ramah lingkungan dan Pelaksanaan kebijakan lingkungan hidup belum sesuai dengan perencanaan.

3. Upaya-upaya yang dilakukan oleh Dinas Lingkungan Hidup Kota Semarang dalam mengatasi kendala atau hambatan terhadap pelaksanaan pengelolaan pembangunan berwawasan lingkungan di kota Semarang, antara lain dengan pengelolaan sumber daya alam direncanakan sesuai dengan daya dukung, dibangun sesuai dengan zona industri, zona pemukiman, zona perkebunan, Pengendalian kerusakan lingkugnan dan perencanaan tata ruangan 


\section{DAFTAR PUSTAKA}

\section{A. Buku-buku :}

Abdurahmam, 1993. Pengantar Hukum Lingkungan Indonesia. Alumni. Bandung.

Ali, Hasyimi. A. 2002. Organisasi dan Manajemen, Bumi Aksara, Jakarta.

Arief Hidayat dan FX. Adji Samekto, 2007, Kajian Kritis Penegakan Hukum Lingkungan di Era Otonomi Daerah, BP. Undip, Semarang, hal.9

Arifin, S. 2012. Hukum Perlindungan Dan Pengelolaan Lingkungan Hidup Di Indonesia. Sofmedia. Jakarta.

Emil Salim, 1986, Pembangunan Berwawasan Lingkungan, LP3S, Jakarta

Emil Salim. 1995. Lingkungan Hidup dan Pembangunan. Mitra Sumber Widya. Jakarta.

Huijbers, T. 1982. Filsafat Hukum dalam Lintasan Sejarah. Kanisius. Yogyakarta.

Hartono.2009. Geografi Jelajah Bumi dan Alam Semesta. CV Citra Praya. Jakarta.

Joni. 2015. Hukum Lingkungan Kehutanan. Pustaka Pelajar. Yogyakarta.

Koesnadi Hardjasoemantri, 1993. Hukum Tata Lingkungan. cetakan kesepuluh. Gajah Mada University Press. Yogyakarta.

Kementerian Lingkungan Hidup. 2010. Sekilas Tentang AMDAL. Kementerian Lingkungan Hidup. Jakarta.

Machmud, S. 2012. Penegakan Hukum Lingkungan Indonesia. Graha Ilmu. Yogyakarta.

Munadjat Danusaputro, 1981. Hukum lingkungan II Nasional. Binacipta. Bandung

Mustofa, H.A. 2005. Kamus Lingkungan. Penerbit Rineka Cipta. Jakarta.

Pongtuluran Yonathan.2015. Manajemen Sumber Daya Alam dan Lingkungan. CV Ansi Offset. Yogyakarta 
Rivai, Veithzal. 2004. Kepemimpinan dan Prilaku Organisasi (edisi kedua). PT Raja Grafindo Persada, Jakarta.

Rahmadi, T. 2011. Hukum Lingkungan di Indonesia. Raja Grafindo Persada. Jakarta.

Soemartono, Gatot P. 1991. Mengenal Hukum Lingkungan Indonesia. Sinar Grafika. Jakarta.

Sunyoto, Danang dan Burhanudin. 2011. Prilaku Organisasi (cetakan pertama), PT Buku Seru. Jakarta.

Supriadi. 2010. Hukum Lingkungan Di Indonesia. Sinar Grafika. Jakarta.

Siahaan. 2004. Hukum Lingkungan dan Ekologi Pembangunan. Erlangga.

Jakarta.

Siahaan, N.H.T. 2008. Hukum Lingkungan. Pancuran Alam. Jakarta.

St. Munadjat Danusaputro, 1984, Hukum Lingkungan Buku V: Sektoral Jilid 5, Bina Cipta, Bandung.

Siti Sundari Rangkuti, 1996, Hukum Lingkungan dan Kebijaksanaan Lingkungan Nasional, Erlangga University Press, Surabaya.

B. Peraturan Perundang-undangan :

Undang-Undang Dasar Negara Republik Indonesia Tahun 1945

Undang-Undang Republik Indonesia Nomor 23 Tahun 1997 tentang Pengelolaan Lingkungan Hidup.

Undang-Undang Republik Indonesi Nomor 4 Tahun 1982 tentang KetentuanKetentuan Pokok Pengelolaan Lingkungan Hidup.

Undang-Undang Republik Indonesi Nomor 10 Tahun 1992 tentang Perkembangan Kependudukan dan Pembangunan Keluarga Sejahtera.

Undang-Undang Republik Indonesi Nomor 32 Tahun 2004 tentang Pemerintah Daerah.

Undang-Undang Republik Indonesi Nomor 32 Tahun 2009 Tentang Perlindangan dan Pengelolaan Lingkungan Hidup

Peraturan Pemerintah Republik Indonesi Nomor 27 Tahun 1999 tentang Analisis Mengenai Dampak Lingkungan. 
Peraturan Daerah Provinsi Jawa Tengah Nomor 5 Tahun 2007 tentang Pengendalian Lingkungan Hidup di Provinsi Jawa Tengah.

Peraturan Daerah Kota Semarang Nomor 13 Tahun 2006 tentang Pengendalian Lingkungan Hidup.

C. Jurnah, Makalah, Artikel :

Absori. 2004, "Peran Serta Masyarakat Dalam Pembuatan AMDAL," Jurnal Jurisprudence, Nomor 2 (September, 2004).

Dian Arival Aryadana, 2015, Peran Badan Pengendalian Dampak Lingkungan Daerah Dalam Pengendalian Pencemaran Terhadap Kegiatan Industri Di Kota Batam Tahun 2011-2014, Jurnal Vol. 2 No.2 (Oktober, 2015). 